\title{
Profil Kemampuan Koneksi Matematis Mahasiswa dalam Menyelesaikan Masalah Matematika Berdasarkan Level Kemampuan Akademik
}

\author{
Suhandri, Hayatun Nufus, Erdawati Nurdin ${ }^{*}$ \\ Pendidikan Matematika, UIN Sultan Syarif Kasim Riau, \\ Jl. HR. Soebrantas No. 155 Pekanbaru, Indonesia \\ ${ }^{*}$ E-mail: erdawati.nurdin@uin-suska.ac.id
}

Dikirim: 23 Agustus 2017 ; Diterima: 08 November 2017; Dipublikasikan: 20 Desember 2017

\begin{abstract}
Abstrak. Tujuan penelitian ini adalah untuk mendeskripsikan kemampuan koneksi matematis mahasiswa dalam menyelesaikan masalah matematis berdasarkan level kemampuan akademik pada matakuliah Kalkukus Diferensial. Metode penelitian yang dilakukan adalah penelitian deskriptif kualitatif terhadap kemampuan koneksi matematis 29 orang mahasiswa UIN Sultan Syarif Kasim Riau yang sedang mengambil matakuliah Persamaan Diferensial Biasa. Instrumen yang digunakan adalah instrumen tes kemampuan koneksi matematis beserta alternatif jawabannya, lembar pedoman wawancara, dan lembar validasi. Teknik pengumpulan data dalam penelitian ini terdiri atas teknik tes, teknik wawancara, dan penyebaran angket. Analisis data dilakukan dengan dua cara, yakni analisis data tertulis dilakukan dengan cara mengecek kebenaran jawaban yang diberikan oleh mahasiswa terhadap tes soal kemampuan koneksi matematis dan analisis data hasil wawancara dilakukan dengan mereduksi data. Dari analisis data ditemukan bahwa skor rata-rata kemampuan koneksi matematis mahasiswa secara keseluruhan adalah 3,65. Dan skor rata-rata kemampuan koneksi matematis mahasiswa adalah 3,55 untuk level akademik tinggi, 3,75 dan 3,64 untuk masing-masing level akademik sedang dan rendah. Hasil penelitian menunjukkan bahwa mahasiswa UIN Sultan Syarif Kasim Riau memiliki kemampuan koneksi matematis yang tinggi dalam menyelesaikan masalah matematika pada matakuliah Kalkulus Diferensial baik dipandang secara keseluruhan maupun berdasarkan level akademik.
\end{abstract}

Kata Kunci. Kemampuan Koneksi Matematis, Level Kemampuan Akademik, Masalah Matematis.

\section{Pendahuluan}

Satu dari beberapa gagasan utama yang menjadi wacana menarik dalam komunitas pendidikan matematika adalah ungkapan "mahasiswa harus memahami

matematika". Untuk itulah, pembelajaran matematika dengan pemahaman sering menjadi bahan kajian yang sangat luas dan 
mendalam dalam riset pendidikan matematika. Hampir semua teori belajar menjadikan pemahaman sebagai tujuan dari proses pembelajaran. Sebagaimana yang termuat dalam Permendikbud No. 70 Tahun 2013, bahwa salah satu kompetensi inti yang harus dimiliki oleh peserta didik adalah memahami, menerapkan dan menganalisis pengetahuan (Kemendikbud, 2013).

Pengetahuan yang telah diperoleh melalui pemahaman akan menjadi dasar dalam pengembangan pengetahuan baru dan berguna sebagai penyelesaian baru dalam pemecahan masalah-masalah yang tidak biasa (unfamiliar). Ketika mahasiswa telah memperoleh pemahaman konseptual dalam matematika, mereka akan melihat koneksi antara konsep dan prosedur dan juga memberikan argumen mengapa beberapa fakta atau kenyataan sebagai konsekuensi dari fakta lainnya. Semakin mereka paham maka semakin baik pula kemampuan mereka dalam mengkoneksikan matematika (Kusmanto dan Marliyana, 2014). Mereka lebih percaya diri sehingga dapat mengantarkan mereka untuk mempelajari konsep yang lebih tinggi. Inilah yang dikatakan sebagai kemampuan koneksi matematis.

Kemampuan koneksi matematis sangat diperlukan sejak dini oleh setiap peserta didik termasuk di dalamnya mahasiswa. Dengan koneksi, mereka dapat membangun pemahaman baru dari pengetahuan sebelumnya (NCTM, 2000) Menurut Sumarmo (2013) jika siswa mampu melakukan koneksi antar beberapa ide matematis, maka mereka akan memahami setiap materi matematika dengan lebih dalam dan baik. Melalui koneksi, konsep pemikiran dan wawasan mahasiswa akan semakin terbuka dan luas terhadap matematika karena mereka akan memandang matematika sebagai suatu bagian yang terintegrasi bukan sebagai sekumpulan topik yang terpisah-pisah, serta mengakui adanya keterkaitan atau hubungan dan aplikasi di dalam kehidupan atau lingkungan sekitar mereka. Karena topik-topik dalam matematika banyak memiliki relevansi dengan disiplin ilmu lain, baik di kelas maupun di luar kelas. Pernyataan ini didukung oleh Afgani (2011), bahwa koneksi matematis didasarkan pada konsep bahwa matematika sebagai ilmu yang terstruktur dan utuh, yang terdiri dari bagian-bagian yang saling berhubungan.

Dalam melakukan suatu koneksi matematis, tentu sangat dipengaruhi oleh kecerdasan. Berdasarkan penelitian yang dilakukan oleh (Sunantina, 2016) diketahui bahwa kecerdasan matematis berpengaruh 
signifikan terhadap prestasi belajar matematika, tentunya termasuk kemampuan koneksi matematis. Berbicara tentang kecerdasan, tingkat kecerdasan mahasiswa beragam, ada yang pandai, sedang-sedang saja, dan lemah.. Terdapat mahasiswa pendidikan matematika cenderung memiliki rasa kurang percaya diri dalam mengomunikasikan ide-ide matematis, kurang mampu memberikan argumentasi yang tepat sesuai dengan fakta, prinsip dan prosedur matematis (Sugilar, 2017). Hal ini didukung oleh Galton (Ruseffendi, 2006) yang mengemukakan bahwa dari sekelompok mahasiswa yang dipilih secara sebarang (tidak dipilih secara khusus), akan dijumpai mahasiswa yang berkemampuan tinggi, sedang, dan rendah yang menyebar secara berdistribusi normal

Jadi, dapat dikatakan bahwa kecerdasan matematis akan mempengaruhi kemampuan koneksi matematis dan kemampuan matematis memiliki peranan yang sangat besar dalam pembelajaran matematika. Oleh karena itu, sangatlah penting untuk diteliti sejauh mana mahasiswa memiliki kemampuan koneksi matematis dalam menyelesaikan permasalahan matematika yang ada dilihat dari kecerdasan matematis, yang dalam penelitian ini disebut level kemampuan akademik. Selanjutnya, karena salah satu materi yang banyak memiliki koneksi (baik koneksi antar topik matematika maupun dengan bidang lain serta kehidupan seharihari) adalah materi kalkulus diferensial, maka perlu pula diteliti kemampuan koneksi matematis berdasarkan level kemampuan akademik pada materi kalkulus diferensial.

Berdasarkan pernyataan tersebut, maka rumusan masalah pada penelitian ini adalah bagaimana profil kemampuan koneksi matematis mahasiswa dalam menyelesaikan masalah matematika berdasarkan level kemampuan akademik pada matakuliah kalkulus diferensial?

\section{Metodologi Penelitian}

Jenis penelitian yang digunakan dalam penelitian ini adalah deskriptif kualitatif. Menurut Sukmadinata (2011), penelitian deskriptif ditujukan untuk mendeskripsikan fenomena-fenomena ynag ada, baik yang bersifat alamiah maupun yang rekayasa manusia. Penelitian deskriptif tidak memberikan perlakuan atau pengubahan pada variabel-variabel bebas, tetapi menggambarkan suatu kondisi apa adanya. Artinya peneliti tidak melakukan manipulasi atau memberikan perlakuan tertentu terhadap variabel atau merancang sesuatu yang yang diharapkan terjadi pada variabel, tetapi semua kegiatan, keadaan, 
kejadian, aspek, komponen atau variabel berjalan sebagaimana adanya. Satu-satunya unsur manipulasi atau perlakuan yang yang diberikan hanyalah penelitian itu sendiri, yang dilakukan melalui observasi, wawancara, pengedaran angket atau studi dokumentasi.

Penelitian ini dilaksanakan di Program Studi Pendidikan Matematika Fakutas Tarbiyah dan Keguruan UIN Suska Riau dengan. Subjek penelitian dalah 29 orang mahasiswa semester lima yang sedang mengambil matakuliah Persamaan Diferensial Biasa yang dipilih secara acak. Hal ini karena mahasiswa sedang mengambil mata kuliah Persamaan Diferensial Biasa, yang mengharuskan mereka paham dengan baik tentang konsep turunan/diferensial (materi yang terdapat pada mata kuliah kalkulus diferensial).

Instrumen pengumpulan data terdiri atas: (1) instrumen tes kemampuan koneksi matematis beserta alternatif jawabannya dengan penskoran berdasarkan kriteria pedoman penskoran kemampuan koneksi matematis yang diungkapkan oleh Lane (Nurdin, 2012) pada Tabel 1, (2) lembar pedoman wawancara, dan (3) lembar angket validasi soal.

Tabel 1. Kriteria Pedoman Penskoran Kemampuan Koneksi Matematis

\begin{tabular}{cccc}
\hline Skor & \multicolumn{3}{c}{ Kriteria Jawaban dan Alasan } \\
\hline $\mathbf{4}$ & Menunjukkan & pemahaman & terhadap \\
\hline
\end{tabular}

\begin{tabular}{|c|c|}
\hline Skor & Kriteria Jawaban dan Alasan \\
\hline & $\begin{array}{l}\text { konsep dan proses matematis soal, } \\
\text { menggunakan istilah dan notasi yang } \\
\text { tepat, melaksanakan algoritma secara } \\
\text { benar dan lengkap. }\end{array}$ \\
\hline 3 & $\begin{array}{l}\text { Pemahaman yang baik terhadap } \\
\text { konsep dan proses matematis soal, } \\
\text { menggunakan istilah dan notasi yang } \\
\text { hampir benar, melaksanakan algoritma } \\
\text { secara lengkap dan secara umum } \\
\text { perhitungan benar, tetapi masih } \\
\text { terdapat kesalahan. }\end{array}$ \\
\hline 2 & $\begin{array}{l}\text { Hampir memahami konsep dan proses } \\
\text { matematis soal, mengidentifikasi } \\
\text { unsur-unsur penting, namun banyak } \\
\text { ide-ide yang keliru, melakukan } \\
\text { beberapa kesalahan perhitungan. }\end{array}$ \\
\hline 1 & $\begin{array}{l}\text { Memahami sebagian konsep dan } \\
\text { proses matematis soal, menggunakan } \\
\text { alat dan strategi penyelesaian yang } \\
\text { tidak tepat dan melakukan banyak } \\
\text { kesalahan perhitungan. }\end{array}$ \\
\hline 0 & $\begin{array}{l}\text { Tidak ada penjelasan jawaban } \\
\text { Skor Ideal = 4 }\end{array}$ \\
\hline
\end{tabular}

Teknik pengumpulan data dalam penelitian ini terdiri atas teknik tes, teknik wawancara dan penyebaran angket. Teknik tes digunakan untuk memperoleh data kemampuan koneksi matematis mahasiswa. Tes dilakukan dalam setting ruangan kelas yang dilakukan secara bersamaan. Masing-masing mahasiswa disediakan dua lembar kertas jawaban dan satu lembar coretan. Sedangkan teknik wawancara dilakukan untuk memperoleh data yang lebih mendalam tentang kemampuan mahasiswa terkait koneksi matematis melalu serangkaian pertanyaan yang diajukan secara lisan. Wawancara ini dilakukan setelah peneliti memperoleh data tertulis berupa jawaban mahasiswa terhadap soal tes kemampuan koneksi 
matematis. Mahasiswa yang diwawancarai dipilih secara acak masing-masing dua orang untuk tiap level kemampuan akademik. Nilai untuk menentukan level kemampuan akademik mahasiswa diambil dari nilai matakuliah Kalkulus Diferensial yang telah diambil pada semester dua. Pengelompokan level kemampuan akademik berdasarkan tabel berikut :

Tabel 2. Kriteria Pengelompokan Level Kemampuan Akademik

\begin{tabular}{cc}
\hline Level Kemampuan & Rentang Nilai \\
\hline Tinggi & $x \geq \bar{x}+\sigma$ \\
Sedang & $\bar{x}-\sigma<x<\bar{x}+\sigma$ \\
Rendah & $x \leq \bar{x}-\sigma$ \\
\hline
\end{tabular}

Keterangan:

$x=$ skor kemampuan koneksi matematis masing-masing mahasiswa

$\bar{x}=$ rata-rata skor kemampuan koneksi matematis mahasiswa

$\sigma=$ simpangan baku skor kemampuan koneksi matematis mahasiswa

Dengan rumus simpangan baku $(s)$ adalah akar dari varians $\left(s^{2}\right)$ berdasarkan Sudjana (2005):

$$
s^{2}=\frac{\sum\left(x_{i}-\bar{x}\right)^{2}}{n-1}
$$

Penyebaran angket dilakukan untuk memperoleh data terkait dengan kevalidan soal tes kemampuan koneksi matematis dan pedoman wawancara yang peneliti gunakan. Angket diberikan kepada validator yang sesuai dengan keahlian sebagaimana terkait dengan indikator aspek valid yang peneliti tentukan.
Selanjutnya, data dianalisis menggunakan langkah-langkah berikut:

a. Analisis data tertulis dilakukan dengan cara mengecek kebenaran jawaban yang diberikan oleh mahasiswa terhadap tes soal kemampuan koneksi matematis berdasarkan petunjuk penyelesaian dan kunci jawaban yang disediakan oleh peneliti. Selanjutnya menarik kesimpulan dari data yang telah dikumpulkan dan memverifikasi kesimpulan tersebut.

b. Analisis data hasil wawancara dilakukan dengan mereduksi data yaitu kegiatan yang mengacu pada proses pemilihan, pemusatan perhatian dan transformasi data mentah di lapangan. Apabila terdapat data yang tidak valid, maka data itu dikumpulkan tersendiri dan mungkin dapat digunakan untuk hasil-hasil sampingan lainnya. Selanjutnya menarik kesimpulan dari data yang telah dikumpulkan dan memverifikasi kesimpulan tersebut.

Adapun prosedur penelitian yang dilakukan adalah :

a. Merumuskan masalah yang akan diteliti, yaitu mendeskripsikan kemampuan koneksi matematis mahasiswa dalam menyelesaikan masalah matematika berdasarkan level 
kemampuan akademik pada matakuliah kalkulus diferensial.

b. Menentukan populasi dan memilih sampel penelitian. Sampel penelitian ini dipilih dengan teknik sampling purposive, yaitu teknik penentuan sampel dengan pertimbangan tertentu (Sugiyono, 2014). Mahasiswa semester $\mathrm{V}$ yang sedang mengambil matakuliah Persamaan Diferensial Biasa (PDB) dipilih sebagai sampel pada penelitian ini dikarenakan matakuliah tersebut merupakan salah satu matakuliah dengan prasyarat kalkulus diferensial. Artinya, matakuliah tersebut hanya bisa diambil oleh mahasiswa yang telah lulus matakuliah kalkulus diferensial di semester III. Jadi, untuk dapat mengikuti matakuliah PDB dengan baik, maka mahasiswa harus memiliki kemampuan koneksi matematis yang baik, khususnya koneksi antar konsep matamatika, dalam hal ini adalah mengenai persamaan diferensial dan kalkulus diferensial.

c. Menyusun instrumen penelitian, berupa soal tes dan angket. Untuk memperoleh data kemampuan koneksi matematis mahasiswa diperlukan teknik tes. Tes yang ditulis disesuaikan dengan indikator kemampuan koneksi matematis. Tes untuk mengukur kompetensi haruslah valid (Zein dan
Darto, 2012). Oleh sebab itu digunakan teknik angket untuk melihat validitas soal tersebut. Soal tes yang digunakan telah divalidasi dan dinyatakan valid oleh validator (ahli). Selain teknik tes dan angket, dilakukan pula teknik wawancara. Wawancara dilakukan untuk memperoleh data yang lebih mendalam tentang kemampuan mahasiswa terkait koneksi matematis melalu serangkaian pertanyaan yang diajukan secara lisan.

d. Melakukan penelitian dengan memberikan soal tes kepada sampel penelitian. Kemudian melakukan analisis terhadap jawaban yang diberikan oleh mahasiswa terhadap tes yang diberikan dan hasil wawancara yang dilakukan.

e. Menyimpulkan hasil penelitian dan analisis data yang telah dilakukan.

\section{Hasil dan Pembahasan}

Penelitian ini bertujuan untuk mendeskripsikan kemampuan koneksi matematis mahasiswa UIN Sultan Syarif Kasim Riau dalam menyelesaikan masalah matematis pada matakuliah kalkulus diferensial. Deskripsi kemampuan matematis mahasiswa dijabarkan dalam indikator berikut :

a. Kemampuan Kemampuan mahasiswa dalam memahami dan menggunakan 
koneksi di antara topik-topik dalam matematika (koneksi antar konsep matematika) yang dalam hal ini diwakili oleh soal tes nomor 1 (a) dan 1 (b).

b. Kemampuan mahasiswa dalam menerapkan matematika dalam bidang lain (koneksi matematika dengan ilmu lain), yang dalam hal ini diwakili oleh soal tes nomor 2 .

c. Kemampuan mahasiswa dalam menerapkan matematika dalam kehidupan sehari-hari (koneksi matematika dengan dunia nyata), yang dalam hal ini diwakili oleh soal tes nomor 3.

Kategori kemampuan koneksi matematis mahasiswa pada penelitian ini dimodifikasi dari pengkategorian skor tes yang dinyatakan oleh Arikunto (2012), yaitu :

Tabel 3. Kategori Kemampuan Koneksi Matematis

\begin{tabular}{cc}
\hline Kategori & Rentang Skor \\
\hline Sangat Baik & $3,40<$ skor $\leq 4$ \\
Baik & $3,00<$ skor $\leq 3,40$ \\
Cukup & $2,40<$ skor $\leq 3,00$ \\
Kurang & $1,80<$ skor $\leq 2,40$ \\
Kurang Sekali & $0<$ skor $\leq 1,80$ \\
\hline
\end{tabular}

Adapun skor rata-rata dan distribusi skor kemampuan koneksi matematis mahasiswa pada matakuliah Kalkulus Diferensial dapat dilihat dari tabel berikut :

Tabel 4. Skor Rata-rata Kemampuan Koneksi Matematis Mahasiswa

\begin{tabular}{ccccccc}
\hline Level & \multicolumn{3}{c}{ Skor Rata-rata } & \multicolumn{1}{c}{$\begin{array}{c}\text { Rata- } \\
\text { rata }\end{array}$} & Total \\
\cline { 2 - 7 } & $\mathbf{1 a}$ & $\mathbf{1 b}$ & $\mathbf{2}$ & $\mathbf{3}$ & & \\
\hline Tinggi & 3,45 & 2,82 & 3,9 & 4 & 3,55 & 14,17 \\
\hline
\end{tabular}

\begin{tabular}{ccccccc}
\hline Level & \multicolumn{3}{c}{ Skor Rata-rata } & $\begin{array}{c}\text { Rata- } \\
\text { rata }\end{array}$ & Total \\
\cline { 2 - 7 } & $\mathbf{1 a}$ & $\mathbf{1 b}$ & $\mathbf{2}$ & $\mathbf{3}$ & & \\
\hline Sedang & 3,73 & 3,27 & 4 & 4 & 3,75 & 15 \\
Rendah & 3,71 & 3,29 & 3,71 & 4 & 3,64 & 14,72 \\
Total & 3,59 & 3,10 & 3,90 & 4 & 3,65 & 14,59 \\
$\begin{array}{c}\text { Skor } \\
\text { Ideal }\end{array}$ & 4 & 4 & 4 & 4 & 4 & 16 \\
St. Dev & 0,63 & 0,56 & 0,31 & 0 & 0,56 & 1,02 \\
\hline
\end{tabular}

Tabel 4 menunjukkan bahwa skor rata-rata kemampuan akademik mahasiswa secara keseluruhan adalah berada pada kategori sangat baik, yaitu dengan skor rata-rata 3,65. Ditinjau dari segi level akademik mahasiswa juga menunjukkan bahwa mahasiswa di setiap level akademik memiliki kemampuan koneksi matematis yang sangat baik. Skor rata-rata tertinggi diperoleh kelompok mahasiswa yang berada pada level akademik sedang, namun hanya berbeda 0,10 poin dari kelompok tinggi dan 0,11 poin dari kelompok rendah. Walaupun terdapat perbedaan skor ratarata di masing-masing level akademik, namun semua kelompok mahasiswa ini sama-sama berada pada kategori kemampuan koneksi matematis yang sangat baik.

Tabel 5 Distribusi Skor Tes Kemampuan Koneksi Matematis Mahasiswa Secara Keseluruhan

\begin{tabular}{ccccc}
\hline Jumlah & \multicolumn{4}{c}{ Soal Nomor Ke- } \\
\cline { 2 - 5 } $\begin{array}{c}\text { Mahasiswa } \\
\text { Mendapat } \\
\text { Skor }\end{array}$ & $\mathbf{1 ( a )}$ & $\mathbf{1}(\mathbf{b})$ & $\mathbf{2}$ & $\mathbf{3}$ \\
$\mathbf{4}$ & 20 & 6 & 26 & 29 \\
$\mathbf{3}$ & 7 & 20 & 3 & 0 \\
$\mathbf{2}$ & 0 & 0 & 0 & 0 \\
$\mathbf{1}$ & 0 & 0 & 0 & 0 \\
$\mathbf{0}$ & 0 & 0 & 0 & 0 \\
\hline
\end{tabular}


Berdasarkan Tabel 4 dan Tabel 5 dapat diuraikan secara ringkas hasil penelitian berdasarkan nilai kemampuan matematis secara keseluruhan sebagai berikut :

a. Mahasiswa memiliki kemampuan koneksi matematis yang sangat baik untuk aspek kemampuan mahasiswa dalam memahami dan menggunakan koneksi di antara topik-topik dalam matematika (koneksi antar konsep matematika), dengan nilai rata-rata 3,59 dari skor ideal 4. Untuk soal no.1(a) terdapat 20 orang $(69 \%)$ mahasiswa mampu menjawab dengan sempurna dan 6 orang (21\%) untuk soal no. 1(b).

b. Untuk aspek kemampuan mahasiswa dalam menerapkan matematika dalam bidang lain (koneksi matematika dengan ilmu lain) berada kategori baik, dengan rata-rata 3,10 dari skor ideal 4 dan terdapat 26 orang $(90 \%)$ mahasiswa mampu memberikan jawaban yang benar dan lengkap.

c. Untuk aspek kemampuan mahasiswa dalam menerapkan matematika dalam kehidupan sehari-hari (koneksi matematika dengan dunia nyata), semua mahasiswa mendapatkan skor sempurna, yaitu 4 (kategori kemampuan koneksi matematis baik sekali). Artinya, $100 \%$ mahasiswa telah mampu memahami konsep matematika yang berhubungan dengan kehidupan nyata. d. Secara keseluruhan mahasiswa UIN Sultan Syarif Riau memiliki kemampuan koneksi matematis yang sangat baik di segala aspek, baik koneksi antar topik matematika, koneksi matematika dengan bidang lain serta koneksi matematika terhadap kehidupan sehari-hari, dengan nilai rata-rata 14,59.

Tabel 6. Distribusi Skor Tes Kemampuan Koneksi Matematis Mahasiswa Berdasarkan Level Kemampuan Akademik

\begin{tabular}{|c|c|c|c|c|c|}
\hline \multirow{2}{*}{$\begin{array}{c}\text { Level } \\
\text { Kemampuan } \\
\text { Akademik }\end{array}$} & \multirow{2}{*}{$\begin{array}{c}\text { Jumlah } \\
\text { Mahasiswa } \\
\text { Mendapat } \\
\text { Skor }\end{array}$} & \multicolumn{4}{|c|}{ Soal Nomor Ke- } \\
\hline & & $1 \mathbf{a}$ & 1b & 2 & 3 \\
\hline \multirow[t]{5}{*}{ Tinggi } & 4 & 6 & 0 & 10 & 11 \\
\hline & 3 & 4 & 9 & 1 & 0 \\
\hline & 2 & 1 & 2 & 0 & 0 \\
\hline & 1 & 0 & 0 & 0 & 0 \\
\hline & $\mathbf{0}$ & 0 & 0 & 0 & 0 \\
\hline Jumlah & & \multicolumn{4}{|c|}{11} \\
\hline \multirow[t]{5}{*}{ Sedang } & 4 & 8 & 3 & 11 & 11 \\
\hline & 3 & 3 & 8 & 0 & 0 \\
\hline & 2 & 0 & 0 & 0 & 0 \\
\hline & 1 & 0 & 0 & 0 & 0 \\
\hline & $\mathbf{0}$ & 0 & 0 & 0 & 0 \\
\hline Jumlah & & \multicolumn{4}{|c|}{11} \\
\hline \multirow[t]{5}{*}{ Rendah } & 4 & 6 & 3 & 5 & 7 \\
\hline & 3 & 0 & 3 & 2 & 0 \\
\hline & 2 & 1 & 1 & 0 & 0 \\
\hline & 1 & 0 & 0 & 0 & 0 \\
\hline & $\mathbf{0}$ & 0 & 0 & 0 & 0 \\
\hline Jumlah & & \multicolumn{4}{|c|}{7} \\
\hline
\end{tabular}

Berdasarkan Tabel 4 dan Tabel 6 kemampuan koneksi matematis mahasiswa dengan level kemampuan akademik tinggi dapat dijelaskan secara singkat sebagai berikut :

a. Mahasiswa memiliki kemampuan koneksi matematis yang baik untuk aspek kemampuan mahasiswa dalam memahami dan menggunakan koneksi di antara topik-topik dalam matematika 
(koneksi antar konsep matematika), dengan nilai rata-rata 3,14 dari skor ideal 4. Untuk soal no.1(a) terdapat 6 orang $(55 \%)$ mahasiswa mampu menjawab dengan sempurna dan hanya 2 orang (19\%) mahasiswa yang hampir memahami konsep dan ide-ide antar matematika pada soal no. 1(b), selebihnya sudah mampu menjawab dengan baik.

b. Kemampuan koneksi matematis mahasiswa berada pada kategori baik sekali untuk aspek kemampuan mahasiswa dalam menerapkan matematika dalam bidang lain (koneksi matematika dengan ilmu lain). Skor rata-rata yang diperoleh 3,91 dari skor ideal 4 dan terdapat 10 orang (91\%) mahasiswa mampu memberikan jawaban yang benar dan lengkap.

c. Untuk aspek kemampuan mahasiswa dalam menerapkan matematika dalam kehidupan sehari-hari (koneksi matematika dengan dunia nyata), seluruh mahasiswa dengan level kemampuan akademik tinggi (11 orang) mendapatkan skor sempurna, yaitu 4, berada pada kategori baik sekali. Artinya, 100\% mahasiswa telah mampu memahami konsep matematika yang berhubungan dengan kehidupan nyata.

d. Mahasiswa pada level akademik tinggi memiliki kemampuan koneksi matematis yang sangat baik, skor ratarata yang diperoleh adalah 14,18 dari skor ideal 16.

Untuk kemampuan koneksi matematis mahasiswa dengan level kemampuan akademik sedang dapat dijelaskan secara singkat sebagai berikut :

a. Mahasiswa memiliki kemampuan koneksi matematis yang sangat baik untuk aspek kemampuan mahasiswa dalam memahami dan menggunakan koneksi di antara topik-topik dalam matematika (koneksi antar konsep matematika), dengan nilai rata-rata 3,50 dari skor ideal 4. Skor minimal untuk aspek ini adalah 3, artinya mahsiswa pada level kemampuan akademik sedang sudah mampu melakukan koneksi matematika kepada bidang lain.

b. Untuk aspek kemampuan mahasiswa dalam menerapkan matematika dalam bidang lain (koneksi matematika dengan ilmu lain) dan aspek kemampuan mahasiswa dalam menerapkan matematika dalam kehidupan seharihari (koneksi matematika dengan dunia nyata), seluruh mahasiswa dengan level kemampuan akademik sedang (11 orang) mendapatkan skor sempurna, yaitu 4, berada pada kategori sangat baik. Artinya, 100\% mahasiswa pada level ini telah mampu memahami 
konsep matematika yang berhubungan dengan kehidupan nyata.

c. Mahasiswa pada level akademik sedang memiliki kemampuan koneksi matematis yang sangat baik, skor ratarata yang diperoleh adalah 15 dari skor ideal 16, skor rata-rata ini paling tinggi dibandingkan mahasiswa dengan level kemampuan akademik tinggi dan rendah.

Terakhir, untuk kemampuan koneksi matematis mahasiswa dengan level kemampuan akademik rendah dapat dijelaskan secara singkat sebagai berikut :

a. Mahasiswa memiliki kemampuan koneksi matematis yang sangat baik untuk aspek kemampuan dalam memahami dan menggunakan koneksi di antara topik-topik dalam matematika (koneksi antar konsep matematika), dengan nilai rata-rata 3,42 dari skor ideal 4. Untuk soal no.1(a) terdapat 5 orang $(71 \%)$ mahasiswa mampu menjawab dengan sempurna dan 3 orang (43\%) mahasiswa telah mampu memahami konsep dan ide-ide antar matematika denagn baik pada soal no. 1(b).

b. Untuk aspek kemampuan mahasiswa dalam menerapkan matematika dalam bidang lain (koneksi matematika dengan ilmu lain) berada kategori sangat baik.
Skor rata-rata yang diperoleh 3,71 dari skor ideal 4 dan terdapat 5 orang $(71 \%)$ mahasiswa mampu memberikan jawaban yang tepat dan lengkap.

c. Untuk aspek kemampuan mahasiswa dalam menerapkan matematika dalam kehidupan sehari-hari (koneksi matematika dengan dunia nyata), seluruh mahasiswa dengan level kemampuan akademik rendah (7 orang) mendapatkan skor sempurna, yaitu 4 (kategori sangat baik). Artinya, 100\% mahasiswa telah mampu memahami konsep matematika yang berhubungan dengan kehidupan nyata.

d. Mahasiswa pada level akademik rendah memiliki kemampuan koneksi matematis yang sangat baik, skor ratarata yang diperoleh adalah 14,57 dari skor ideal 16, skor ini lebih tinggi dibandingkan skor rata-rata yang diperoleh siswa di kelompok tinggi.

Dari uraian tersebut dapat dikatakan bahwa rata-rata skor kemampuan koneksi matematis mahasiswa UIN Sultan Syarif Kasim Riau secara keseluruhan adalah 14,59, dengan seluruh mahasiswa mendapatkan nilai di atas 13 dari skor ideal 16. Nilai ini menunjukkan bahwa mahasiswa UIN Sultan Syarif Kasim Riau sudah memiliki kemampuan koneksi matematis yang sangat baik. Berdasarkan 
level kemampuan akademikpun, baik mahasiswa di level tinggi, sedang maupun rendah, mahasiswa menunjukkan kemampuan koneksi matematis yang tinggi, terutama pada indikator penerapan konsep matematika dalam kehidupan sehari-hari (soal no.3).

Dari Tabel 4 dapat diketahui bahwa penyebaran kemampuan koneksi matematis mahasiswa kecil, dengan simpangan baku 1,02. Hal ini terutama terlihat pada aspek koneksi matematika dengan kehidupan sehari-hari, semua mahasiswa menjawab dengan benar, standar deviasinya nol. Artinya, semua mahasiswa sudah mampu menunjukkan pemahaman terhadap konsep, proses matematis soal, menggunakan istilah dan notasi yang tepat dan mampu melaksanakan algoritma secara benar dan lengkap. Begitu pula untuk soal-soal yang lain, hampir seluruh mahasiswa dapat menjawab dengan baik soal yang diberikan. Untuk indikator koneksi antar konsep matematika (no. 1a), hanya 9 orang $(31 \%)$ yang tidak menjawab dengan tepat, 5 berasal dari level kemampuan tinggi, 3 dari level sedang dan hanya 1 orang dari level rendah. Untuk indikator koneksi matematika dan bidang lainpun (no. 2) hasilnya hampir sama, 26 orang (90\%) mahasiswa dapat menjawab soal dengan benar, 10 orang (91\%) mahasiswa level tinggi, 11 orang (100\%) mahasiswa level sedang dan 5 orang (71\%) mahasiswa level rendah. Dan semua mahasiswa memberikan jawaban pada setiap soal, dengan skor paling rendah 2. Artinya, kemampuan koneksi matematis mahasiswa paling rendah berada pada kriteria hampir memahami konsep dan proses matematis soal, mampu mengidentifikasi unsur-unsur penting, namun banyak ide-ide yang keliru serta melakukan beberapa kesalahan dalam perhitungan. Padahal dari hasil validasi soal tes, soal tes yang diberikan merupakan soal yang memiliki tingkat kesukaran sedang dan sulit. Seharusnya terdapat mahasiswa yang tidak dapat menyelesaikan soal ini secara sempurna.

Hasil penelitian yang diperoleh mengidentifikasikan bahwa kemampuan koneksi matematis mahasiswa seragam (tidak bervariasi), dan berada pada kategori sangat baik. Artinya, semua semua mahasiswa dapat menjawab soal tes kemampuan koneksi matematis dengan benar dan lengkap serta menunjukkan pemahaman konsep dan proses matematis yang tepat. Hal ini juga terjadi pada setiap level kemampuan akademik, baik mahasiswa pada level tinggi, sedang maupun rendah memiliki kemampuan koneksi matematis yang sangat baik. Jika 
dipandang dari masing-masing mahasiswa, kemampuan koneksi matematisnya juga berada pada kategori sangat baik. Dari 29 orang mahasiswa yang diuji, hanya 1 orang yang berada pada kategori baik dan 1 orang mahasiswa pada kategori cukup, sedangkan sisanya sebanyak 27 orang (93\%) mahasiswa menunjukkan kemampuan koneksi matematis yang sangat baik.

Keseragaman kemampuan koneksi matematis ini bertentangan dengan pendapat Galton (Rusefendi, 2006) yang menyatakan bahwa mahasiswa yang dipilih secara acak akan dijumpai mahasiswa yang berkemampuan (termasuk kemampuan koneksi matematis) yang berkemampuan tinggi, sedang dan rendah. Pernyataan Galton ini juga didukung oleh hasil penelitian yang dilakukan Kusmanto dan Marliyana (2014), bahwa pemahaman ataupun kecerdasan matematika (level kemampuan akademik) memberikan pengaruh terhadap kemampuan koneksi matematis, semakin tinggi levelnya semakin tinggi pula kemampuan koneksinya. Latif dan Akib (2016) juga menyatakan hal yang sama, bahwa peserta didik yang memiliki kemampuan matematis tinggi dapat menyelesaikan persoalan matematis, sedangkan peserta didik yang memiliki kemampuan matematis rendah tidak dapat menyelesaikan soal dengan baik. Minarti dan Afgani (2013) mengungkapkan bahwa tingkat kemampuan matematis siswa merupakan salah satu faktor yang dapat mempengaruhi kemampuan koneksi matematis siswa. Siswa dengan kemampuan matematis tinggi memiliki kemampuan koneksi matematis yang lebih baik dibanding siswa dengan kemampuan matematis sedang dan rendah.

Kemungkinan faktor yang menjadi penyebab tidak terjadinya variasi kemampuan koneksi matematis mahasiswa adalah model soal tes kemampuan koneksi matematis yang diujikan pada penelitian ini sudah pernah diujikan (dalam bentuk dan waktu lain) atau soal-soal tes tersebut memiliki kemiripan dengan soal yang pernah dikerjakan oleh mahasiswa yang menjadi subjek pada penelitian ini. Hal ini tentunya menyebabkan soal-soal tes kemampuan koneksi matematis tersebut tidak lagi menjadi soal berpikir tingkat tinggi, namun hanya menjadi soal rutin biasa yang dengan mudah dapat diselesaikan oleh mahasiswa. Mahasiswa yang diberikan soal-soal tes kemampuan koneksi matematis ini juga telah mengetahui bahwa mereka akan menjadi subjek penelitian, sehingga mereka telah mempersiapkan diri sebelum diadakan tes. 
Namun, kemungkinan ini masih harus dikaji lebih mendalam, agar diketahui penyebab pasti keseragaman nilai tes kemampuan matematis mahasiswa.

\section{Simpulan dan Saran}

\section{Simpulan}

Tujuan penelitian ini adalah untuk mendeskripsikan bagaimana tingkat kemampuan koneksi matematis mahasiswa UIN Sultan Syarif Kasim Riau dalam menyelesaikan masalah matematis pada matakuliah Kalkulus Diferensial. Analisis data yang dilakukan secara deskriptif kualitatif menunjukkan bahwa mahasiswa UIN Sultan Syarif Kasim Riau memiliki kemampuan koneksi matematis yang sangat baik. Kemampuan koneksi matematis mahasiswa berdasarkan level akademik, baik tinggi, sedang maupun rendah berada pada kategori sangat baik. Hal ini bertentangan dengan pendapat Galton (Ruseffendi, 2006) bahwa dalam suatu kumpulan mahasiswa seharusnya terdapat berbagai level kemampuan.

Seragamnya kemampuan koneksi matematis mahasiswa ini mengindikasikan kemungkinan terjadinya kesalahan dalam proses penelitian. Oleh sebab itu, perlu dilakukan pengkajian ulang dan lebih mendalam mengenai hal tersebut. Namun karena keterbatasan waktu, peneliti tidak dapat melanjutkan penelitian ini dengan segera.

Hasil penelitian ini dapat dijadikan acuan bagi dosen yang mengajar matakuliah yang memiliki prasyarat matakuliah kalkulus diferensial, untuk memberikan pembelajaran yang lebih menantang atau memberikan challange kepada mahasiswa. Hal ini dikarenan mereka telah memiliki kemampuan koneksi matematis yang sangat baik. Artinya, mereka telah memiliki bekal untuk menghadapi tantangan yang lebih agar dapat mengembangkan kemampuan matematis tingkat tinggi (high order thinking) lainnya.

\section{Saran}

Kemungkinan terjadi kesalahan pada saat penelitian ini dilakukan, sehingga hasil yang diperoleh tidak menunjukkan keragaman kemampuan koneksi matematis mahasiswa. Oleh sebab itu, perlu dikaji lebih mendalam mengenai penyebab terjadinya hal ini, dan diperlukan penelitian ulang untuk melihat kemampuan koneksi matematis mahasiswa yang sebenar-benarnya.

Selain itu, untuk memperoleh data yang lebih akurat dan pembagian kelompok level kemampuan akademik, sebaiknya mahasiswa diberikan tes kemampuan awal 
(dalam bentuk tes kemampuan koneksi matematis) agar dapat mencerminkan kemampuan yang sebenarnya dari setiap mahasiswa.

\section{Ucapan Terima}

Terima kasih kami ucapkan kepada Lembaga Penelitian dan Pengabdian Masyarakat (LPPM) UIN Sultan Syarif Kasim Riau yang membantu pendanaan penelitian ini dari dana DIPA UIN Sultan Syarif Kasim Riau Tahun 2016.

\section{Daftar Pustaka}

Afgani, J. (2011). Analisis Kurikulum Matematika. Jakarta : Universitas Terbuka.

Arikunto, S. (2012). Dasar-Dasar Evaluasi Pendidikan. Jakarta : Bumi Aksara.

Kemendikbud. (2013). Peraturan Menteri Pendidikan dan Kebudayaan Republik Indonesia No. 70 Tahun 2013 Tentang Kerangka Dasar dan Struktur Kurikulum Sekolah Menengah Kejuruan/Madrasah Aliyah Kejuruan. Jakarta : Kemendikbud.

Kusmanto, H \& Marliyana, I. (2014). Pengaruh Pemahaman Matematika Terhadap Kemampuan Koneksi Matematika Siswa Kelas VII Semester Genap SMP Negeri 2 Kasokandel Kabupaten Majalengka. Eduma 3(2), Desember 2014. pp : 61-75

Latif, S \& Akib, I. (2016). Mathematical Connection Ability in Solving Mathematics Problem Based on Initial Abilities of Students at SMPN 10 Bulukumba. Jurnal Daya Matematis 4(2), Juli 2016. pp : 207-217.
Minarti, E.D \& Afgani, J. (2013). Penerapan Model Pembelajaran Generatif (Generative Learning) untuk Meningkatkan Kemampuan Penalaran dan Koneksi Matematis Siswa SMP. Jurnal Pendidikan Matematika : Sigma Didaktika 1(2), Januari 2013. pp : 184-190.

National Council of Teachers of Mathematics (NCTM). (2000). Principles and standard for School Mathematics. Reston: NCTM.

Nurdin, E. (2012). Meningkatkan Kemampuan Pemecahan Masalah dan Koneksi Matematis Siswa Melalui Pendekatan Pembelajaran Visual Thinking. Tesis Universitas Pendidikan Indonesia. Tidak Diterbitkan.

Ruseffendi, H. E. T. (2006). Pengantar kepada Membantu Guru Mengembangkan Kompetensinya dalam Pengajaran Matematika untuk Meningkatkan CBSA. Bandung: Tarsito.

Sudjana. (2005). Metode Statistika. Bandung: Tarsito.

Sugilar, H.(2017). Daya Matematis Mahasiswa Program Studi Pendidikan Matematika. JNPM (Jurnal Nasional Pendidikan Matematika) Vol. 1(1), Hal.97-108. Tersedia [online] http://jurnal.unswagati.ac.id/index.php /JNPM/article/view/252.

Sugiyono. (2014). Metode Penelitian Kuantitatif, Kualitatif dan R\&D. Bandung : Alfabeta

Sukmadinata, N.S. (2011). Metode Penelitian Pendidikan. Bandung: Rosdakarya.

Sumarmo, U. (2013). Kumpulan Makalah Berpikir dan Disposisi Matematik 
Suhandri, Hayatun Nufus, Erdawati Nurdin

Serta Pembelajarannya. Bandung: UPI

Sunantina, A. (2016). Pengaruh Kecerdasan Matematis-Logis terhadap Prestasi Belajar Matematika Materi Luas Bangun Datar Kelas V di SD Muhammadiyah 09 Malang. Skripsi : UIN Maulana Malik Ibrahim. Tidak Diterbitkan.

Zein, M dan Darto. (2012). Evaluasi Pembelajaran Matematika. Pekanbaru : Daulat Riau. 